\title{
Chlorinated drinking water for lightweight laying hens
}

\author{
[Cloração na água de dessedentação para poedeiras leves] \\ A.F. Schneider ${ }^{1}$, D.S. Almeida ${ }^{1}$, A.N. Moraes ${ }^{1}$, L.C.A. Picinin ${ }^{1}$, V. Oliveira ${ }^{2}$, C.E. Gewehr ${ }^{1}$ \\ ${ }^{1}$ Universidade do Estado de Santa Catarina - Lages, SC \\ ${ }^{2}$ Universidade Federal de Santa Maria - Santa Maria, RS
}

\begin{abstract}
The study aimed to evaluate the effect of different levels of chlorine in drinking water of laying hens on zootechnical performance, eggs shell quality, hemogasometry levels and calcium content in tibia. $144 \mathrm{Hy}-$ Line laying hens, 61 weeks old, were used distributed in 24 metabolism cages. They were subjected to water diets, for a period of 28 days, using sodium hypochlorite as a chlorine source in order to obtain the following concentrations: $5 \mathrm{ppm}$ (control), 20ppm, 50ppm, and 100ppm. Their performance was evaluated through water consumption, feed intake, egg production and weight, egg mass, feed conversion. Shell quality was measured by specific gravity. At the end of the experiment, arterial blood was collected for blood gas level assessment and a poultry of each replicate was sacrificed to obtain tibia and calcium content measurement. There was a water consumption reduction from $20 \mathrm{ppm}$ of chlorine and feed intake reduction in poultry receiving water with $100 \mathrm{ppm}$ of chlorine. The regression analysis showed that the higher the level of chlorine in water, the higher the reduction in consumption. There were no differences in egg production and weight, egg mass, feed conversion, specific gravity, tibia calcium content, and hemogasometry levels (hydrogenionic potential, carbon dioxide partial pressure, oxygen partial pressure, sodium, potassium, chloride, bicarbonate, carbon dioxide total concentration, anion gap and oxygen saturation). The use of levels above $5 \mathrm{ppm}$ of chlorine is not recommended in the water of lightweight laying hens.
\end{abstract}

Keywords: chlorine, eggs, hemogasometry, posture, shell

\section{RESUMO}

Objetivou-se avaliar o efeito de diferentes níveis de cloro na água de dessedentação de poedeiras sobre o desempenho zootécnico, a qualidade da casca dos ovos, os índices hemogasométricos e o teor de cálcio na tíbia. Foram utilizadas 144 poedeiras leves Hy Line, de 61 semanas de idade, distribuídas em 24 gaiolas de metabolismo. As aves foram submetidas, durante um período de 28 dias, a dietas hídricas utilizando-se hipoclorito de sódio como fonte de cloro para compor as seguintes concentrações: $5 \mathrm{ppm}$ (controle), 20ppm, 50ppm e 100ppm. O desempenho foi avaliado mediante o consumo de água e ração, a produção e o peso dos ovos, a massa de ovos e a conversão alimentar. A qualidade da casca foi aferida por meio da gravidade específica. Ao final do experimento, coletou-se sangue arterial para avaliação dos índices hemogasométricos e sacrificou-se uma ave de cada repetição para coleta de tíbias e aferição do teor de cálcio. Verificou-se redução do consumo de água a partir de 20ppm de cloro e no consumo de ração em aves que receberam água com 100ppm de cloro. A análise de regressão demonstrou que quanto maior for o nível de cloro na água, maior será a redução no consumo. Não foram observadas diferenças na produção e no peso dos ovos, na massa de ovos, na conversão alimentar, na gravidade específica dos ovos, no teor de cálcio nas tíbias e nos índices hemogasométricos (potencial hidrogeniônico, pressão parcial de gás carbônico, pressão parcial de oxigênio, sódio, potássio, cloro, bicarbonato, concentração total de dióxido de carbono, ânion gap e saturação de oxigênio). Não se recomenda a utilização de níveis superiores a 5ppm de cloro na água de dessedentação de poedeiras leves.

Palavras-chave: casca, cloro, hemogasometria, ovos, postura

Recebido em 5 de outubro de 2015

Aceito em 9 de junho de 2016

E-mail: aline_schneider@hotmail.com 


\section{INTRODUCTION}

Water is an essential nutrient that composes about $70 \%$ of body weight and participates in many biological reactions. Thus, it is important to maintain homeostasis through the control of blood $\mathrm{pH}$, osmotic pressure and various electrolyte concentrations. Poultry may lose all their fat and glycogen, and up to $50 \%$ of body protein; however, the loss of $20 \%$ of water leads to death (Faria et al., 2009). Drinking water disinfection is necessary to remove pathogens and provide quality water to poultry (Amaral et al., 2001). Normative Instruction number 56 of the Ministry of Agriculture, Livestock, and Supply of Brazil requires that poultry farms keep zero level of total coliforms in drinking water (Brasil, 2007). Chlorine is one of the most widely used products for water disinfection, both for humans and animals, presenting satisfactory results when used correctly (Furlan et al., 1999; Valias and Silva, 2001). However, it is worth emphasizing that all chlorinated products have a level of toxicity (Clasen and Edmonson, 2006), and it is recommended to use between 1 and $2 \mathrm{ppm}$ of chlorine in water, both for human and bird consumption (Macari, 1996). Furlan et al. (1999) reported that the addition of $5 \mathrm{ppm}$ of sodium hypochlorite in water reduces the number of bacterial colony forming units and maintains its stable pH. Damron and Flunker (1993) demonstrated that $50 \mathrm{ppm}$ of chlorine in water can reduce water consumption.

Under practical field situations, producers have little control over the chlorine level of water, adding it without many criteria. In this context, chlorine levels in poultry drinking water may be above the ideal amount. Chlorine, sodium, and potassium are part of the physiological processes that influence basic acid balance. They also participate in the metabolism of amino acids, minerals and vitamins, directly affecting birds' performance (Bezerra et al., 2013). Blood levels increased by chlorine reduce hydrogen excretion (decreasing blood $\mathrm{pH}$ ), and bicarbonate reabsorption by the kidneys, and contributes to blood acidification (Borges et al., 2003). Several studies demonstrate that chlorine excess implies egg shell quality deterioration (Gezen et al., 2005).

The use of chlorine in drinking water as a disinfection method is widespread; however, there is a lack of information in the literature, regarding the effects of chlorine excess in water on poultry performance. Therefore, the aim of this study was to evaluate productive performance, egg shell quality, blood gas levels and calcium content of tibias from lightweight laying hens receiving different levels of chlorine in drinking water.

\section{MATERIAL AND METHODS}

An experiment was conducted in the Poultry Sector of Santa Catarina State University, in Lages / SC, using 144 lightweight laying hens of Hy-Line trademark, at 61 weeks old. The laying hens stayed in 24 metabolism cages $(1.0 \times 0.5 \mathrm{~m})$. Each cage contained a chute type feeder and two nipple drinkers connected to PVC pipes, and the pipes connected to a single and closed reservoir with two liter capacity. There were six lightweight laying hens in each cage (experimental unit) that received posture feed with corn, soybean meal, and vegetable oil, formulated according to Rostagno et al., (2005) recommendations and provided ad libitum (Table 1).

The poultry have been receiving a light program of 16 hours of light per day. The laying hens were submitted to four treatments with six replicates, in an entirely randomized design. The treatments consisted of four levels of chlorine in water: 5 (control), 20, 50, and 100ppm. The water came from an artesian well, filtered for the removal of organic matter and was dechlorinated by adding sodium thiosulfate (one drop per liter of water). Thereby, it was possible to ensure they started from zero chlorine level. One day after water dechlorination, liquid chlorine was added (sodium hypochlorite), thus obtaining the desired levels. Different chlorinated solutions were kept in closed buckets, avoiding possible chlorine or water evaporation. The water chlorination process was done daily, using dechlorinated water prepared in the previous day. Water provision was ad libitum, and reservoirs were replenished twice a day, at 12:00 and 6:00pm. The laying hens adapted to water diets for a week and were then assessed for 28 days. 
Table 1. Nutritional and estimated composition of feed

\begin{tabular}{|c|c|}
\hline Feed Ingredients & Inclusion (\%) \\
\hline Maize & 59.40 \\
\hline Soybean meal (45\%) & 20.40 \\
\hline Soybean oil & 3.20 \\
\hline Calcitic lime & 9.00 \\
\hline Nucleus* & 8.00 \\
\hline \multicolumn{2}{|c|}{ Estimated composition } \\
\hline Metabolizable energy (kcal/kg) & 2750 \\
\hline Protein $(\%)$ & 17.00 \\
\hline Calcium $(\%)$ & 4.02 \\
\hline Phosphorus digestible (\%) & 0.375 \\
\hline Methionine digestible (\%) & 0.365 \\
\hline Lysine digestible $(\%)$ & 0.745 \\
\hline Threonine digestible $(\%)$ & 0.575 \\
\hline Valine digestible $(\%)$ & 0.730 \\
\hline Tryptophan digestible (\%) & 0.175 \\
\hline Chlorine $(\%)$ & 0.200 \\
\hline Sodium $(\%)$ & 0.225 \\
\hline \multicolumn{2}{|c|}{ *Nucleus composition: Calcium (maximum) $100 \mathrm{~g} / \mathrm{kg}$, } \\
\hline \multicolumn{2}{|c|}{$\begin{array}{l}\text { Phosphorus (minimum) 37g/kg (3.7\%), Sodium } \\
(\text { minimum) } 20 \mathrm{~g} / \mathrm{kg}, \text { Methionine (minimum) } 17.5 \mathrm{~g} / \mathrm{kg} \text {, } \\
\text { Lysine (minimum) } 18 \mathrm{~g} / \mathrm{kg} \text {, Vitamin A (minimum) } \\
\text { 125000UI } / \mathrm{kg} \text {, Vitamin D3 (minimum) 25000UI } / \mathrm{kg} \text {, }\end{array}$} \\
\hline \multicolumn{2}{|c|}{ 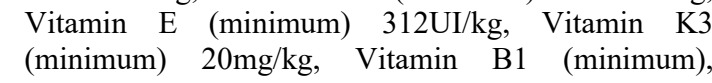 } \\
\hline \multicolumn{2}{|c|}{$20 \mathrm{mg} / \mathrm{kg}$, Vitamin B2 (minimum) $62.5 \mathrm{mg} / \mathrm{kg}$, Vitamin } \\
\hline $200 \mathrm{mcg} / \mathrm{kg}$, Folic acid (minin & um) $\quad 6.25 \mathrm{mg} / \mathrm{kg}$, \\
\hline \multicolumn{2}{|c|}{ 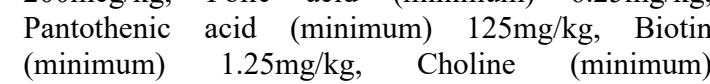 } \\
\hline \multirow{3}{*}{\multicolumn{2}{|c|}{$\begin{array}{l}1700 \mathrm{mg} / \mathrm{kg} \text {, Niacin (minimum) } 312 \mathrm{mg} / \mathrm{kg} \text {, Copper } \\
\text { (minimum) } 125 \mathrm{mg} / \mathrm{kg} \text {, Iron (minimum) 680mg } / \mathrm{kg} \text {, } \\
\text { Iodide (minimum) } 8.75 \mathrm{mg} / \mathrm{kg} \text {, Manganese (minimum) }\end{array}$}} \\
\hline & \\
\hline & \\
\hline $\begin{array}{l}\mathrm{mg} / \mathrm{kg} \text {, Selenum (minimum } \\
\text { himum) } 500 \mathrm{mg} / \mathrm{kg} \text {, Fluor } 99 \mathrm{~ms}\end{array}$ & \\
\hline
\end{tabular}

It was possible to determine the zootechnical performance through water consumption (mL/poultry/day) counted by water supplying pre-weighed in individual reservoirs and remains withdrawn and recorded every day, at $8 \mathrm{am}$. Feed intake ( $\mathrm{g} /$ poultry /day) was evaluated by a weekly supply of a predetermined amount and heavy leftovers at the end of each week. Egg production (\%) was obtained by the total number of eggs produced daily per experimental unit and expressed by the percentage. Egg mass was calculated by the product of egg production (\%) and egg average weight. Feed conversion calculation was from these values, and also, the relation between feed intake and egg mass. Regarding the variables mentioned before, there was an arithmetic average of the four evaluation weeks. It was possible to measure the weight of all eggs produced in the last three days of each week and weighed on an analytical scale $(0.001 \mathrm{~g})$. Shell quality measure was through specific gravity held in the same eggs weighed earlier, soaking them in salt solutions of 1,065 to $1,100 \mathrm{~g} / \mathrm{cm}^{3}$ at intervals of 0.005 and previously measured with a hydrometer.

$1 \mathrm{~mL}$ of arterial blood (from the brachial artery) was collected from one poultry from each experimental unit to evaluate hemogasometry parameters, in the last experimental day. Then, it was immediately analyzed in a gas meter (Blood gas analyzer - Bayer $280 \AA$ - Siemens of São Paulo/SP, Brazil). There was an evaluation of hydrogenionic potential $(\mathrm{pH})$, partial pressure of carbon dioxide $\left(\mathrm{PaCO}_{2}\right)$, partial pressure of oxygen $\left(\mathrm{PaO}_{2}\right)$, sodium levels $\left(\mathrm{Na}^{+}\right)$, potassium $\left(\mathrm{K}^{+}\right)$and chlorine $\left(\mathrm{Cl}^{-}\right)$, bicarbonate $\left(\mathrm{HCO}_{3}{ }^{-}\right)$, total concentration of carbon dioxide $\left(\mathrm{ctCO}_{2}\right)$, anion gap (AnGap), and oxygen saturation $\left(\mathrm{SatO}_{2}\right)$

Tibia calcium content evaluation was through a poultry slaughtering by replicates, which was chosen taking into account the average weight of replicate. After sacrificing it by cervical dislocation, there was a removal of the left tibia that was boiled, stripped, degreased and crushed in a mill. After, it was possible to determine the calcium content following the methodology described by Silva and Queiroz (2004), and using a spectrophotometer of atomic absorption.

The data were statistically analyzed through variance analysis and the means that differed submitted to the Duncan test. The data was also submitted to regression analysis. MIXED procedure was used (Littel et al., 2006) in the statistical computer software SAS ${ }^{\circledR}$ (Statistical Analysis System, 2003). A significance level of up to $5 \%$ was considered for all tests performed.

This paper was submitted to the Ethics Committee in Animal Experimentation CETEA, of the Santa Catarina State University, and approved under protocol number 1.22.11

\section{RESULTS AND DISCUSSION}

From 20ppm of chlorine, it was possible to observe a reduction $(\mathrm{P}<0.05)$ in water consumption (Tab. 2). Water intake with 20 and 
$50 \mathrm{ppm}$ of chlorine decreased in $9.29 \%$, comparing with water with $5 \mathrm{ppm}$ of chlorine. Thus, the reduction was of $17.54 \%$ with $100 \mathrm{ppm}$. The results corroborate those obtained by Damron and Flunker (1993), who observed a water consumption reduction of hens that received water containing $50 \mathrm{ppm}$ of chlorine. Hens present low flavor perception because they have a reduced number of taste buds (approximately 300), and they do not have taste receptors on the tongue and palate to allow them discriminating toxic substances (Macari et al., 2002). Palatability, strictly speaking, refers to a sense measured by taste buds, however, it includes smell, taste, chemical sense, touch, pressure, and it may also be influenced by temperature, color and previous experience of the bird (Kare et al., 1956). In this paper, the strong and characteristic chlorine odor may have contributed to water consumption restriction by poultry, at levels above 5ppm. The data of water intake showed a decreasing linear behavior through the regression analysis, thus, the higher chlorine levels in water result in lower consumption of poultry.

Table 2. Zootechnical performance, egg weight and specific gravity, and calcium content in the tibias from lightweight laying hens receiving drinking water with different levels of chlorine*

\begin{tabular}{lcccccc}
\hline & \multicolumn{7}{c}{ Levels of chlorine in water } & & & \\
\cline { 2 - 7 } \multicolumn{1}{c}{ Variables } & $5 \mathrm{ppm}$ & $20 \mathrm{ppm}$ & $50 \mathrm{ppm}$ & $100 \mathrm{ppm}$ & $\begin{array}{c}\text { Pvalue }- \\
\text { Duncan } \\
\text { Test }\end{array}$ & $\begin{array}{c}\text { P value }- \\
\text { Regression } \\
\text { analysis }\end{array}$ \\
\hline Water consumption (mL) & $182.2 \mathrm{a}$ & $164.5 \mathrm{~b}$ & $166.0 \mathrm{~b}$ & $150.2 \mathrm{c}$ & $<0.001$ & $<0.001^{* *}$ \\
Feed intake (g) & $94.4 \mathrm{a}$ & $91.6 \mathrm{a}$ & $92.3 \mathrm{a}$ & $87.2 \mathrm{~b}$ & $<0.001$ & 0.153 \\
Eggs production (\%) & 81.2 & 75.5 & 80.7 & 75.1 & 0.224 & 0.633 \\
Eggs mass & 50.9 & 47.9 & 50.9 & 47.7 & 0.206 & 0.522 \\
Feed conversion by eggs mass & 1.82 & 1.89 & 1.85 & 1.81 & 0.498 & 0.188 \\
Eggs weight (g) & 63.1 & 63.0 & 63.0 & 62.9 & 0.947 & 0.829 \\
Specific gravity (g/cm ${ }^{3}$ ) & 1086 & 1086 & 1087 & 1086 & 0.852 & 0.744 \\
Calcium content in tibias (\%) & 32.8 & 32.7 & 33.1 & 32.6 & 0.926 & 0.112
\end{tabular}

* Mean values followed by the same letter within the same line do not differ by the Duncan Test $(\mathrm{P}>0.05)$

$* * \mathrm{y}=-11.059 \mathrm{x}+191.92 . \mathrm{R}^{2}=0.9293$

$P$ value: Probability

Macari et al. (2002) report that ingestion of some ions is related to the need for their replacement to maintain the electrolyte balance. Therefore, water consumption reduction with high levels of chlorine could be an alternative used by the hens to prevent homeostasis changes, since small variations are incompatible with life. Water restriction may provoke changes such as respiratory and heart frequency increase, rectal temperature, numbness and/or extremities burning and blood concentration increase, affecting poultry behavior, health, and welfare (Sens, 2010). Furlan et al. (1999), when comparing broiler water intake receiving water with 5ppm of chlorine and non-chlorinated water, found lower consumption in broilers receiving chlorinated water. Nevertheless, the reduction could not change poultry weight gain.

Feed intake (Tab. 2) was also affected $(\mathrm{P}<0.05)$ by chlorine levels in water. Hens that received drinking water with levels of 5, 10 and 20ppm showed similar uptake $(\mathrm{P}>0.05)$, whereas those who received water with $100 \mathrm{ppm}$ presented consumption reductions $(\mathrm{P}<0.05)$. Water restriction causes direct negative effects on feed intake (Sens, 2010). Hamdullah et al., (2010) observed in quails that levels of $200 \mathrm{mg} / \mathrm{L}$ continuously administered for ten weeks resulted in body weight and feed intake reduction. Results may be related to a cumulative toxic effect of chlorine intake through water (Khan et al., 2008). Egg mass and feed conversion per egg mass were not affected by chlorine levels in the water $(\mathrm{P}>0.05)$. Lack of statistical differences in eggs mass derives from similar results observed in egg weight and production. Feed intake reduction by hens that received water with $100 \mathrm{ppm}$ of chlorine, compared to other levels (approximately 6\%), did not cause any changes in feed conversion. The result probably arises from the lack of differences observed in egg mass. Despite higher chlorine levels in water resulting in a reduction in feed and water 
consumption, there were no differences $(\mathrm{P}>0.05)$ in eggs production (Tab. 2). Hamdullah et al., (2010) found that quail laying rate posture was not affected by chlorine levels from 50 to $400 \mathrm{mg} / \mathrm{L}$, for six weeks. However, higher levels caused injuries to some organs, which might be due to direct toxic effect of the chlorine or indirectly by water and food restriction. Other authors have already reported toxic effects because of chlorine excess such as testicular weight reduction (Khan et al., 2008). Papers mentioned above support the importance of chlorine level control in water, since many toxic effects can be observed.

Egg weight and specific gravity (Tab. 2) were not affected by the increase in chlorine levels in water $(\mathrm{P}>0.05)$. Chlorine excess affects the shell quality (Gezen et al., 2005). Austic (1984) states that chlorine is an essential nutrient that alters the shell quality and by providing a diet with high levels of chlorine for laying hens of different ages, there was no significant reduction in egg shell strength and thickness. However, there were no changes in the egg specific gravity, which supports the present paper. Water represents $65 \%$ of the egg's weight (Faria et al., 2009); then, water restriction may result in lower egg weight or even posture declining. If commercial laying hens do not receive water for 48 hours, egg production will probably cease, leading up to 28 days to return to normal production (Leeson and Summers, 1997). Thus, if the restriction period extends there will be adverse effects on egg quality and production. In this study, the chlorine levels tested did not cause any changes in the egg shell quality. However, some researchers report that if chlorine levels increase in the uterine fluid they may cause acidification by inhibiting the carbonic anhydrase enzyme, which restricts the bicarbonate ion supply, limiting calcium uptake and impairing shell quality (Yoselewitz and Balnave, 1989). The divergence between results in papers may relate to resistance differences of the studied poultry groups due to the individual variability found within laying hen populations (Chen and Balnave, 2001). The authors tested sodium chloride solutions $(2 \mathrm{~g} / \mathrm{L})$ in poultry drinking water and reported that some hens continued producing eggs without quality changes while others had their production affected.
There were no differences observed $(\mathrm{P}>0.05)$ in tibia calcium content (Tab. 2). The laying hens have high calcium requirement for eggshell formation and can mobilize up to $40 \%$ of calcium from the medullary bones to the eggshell formation (Cotta, 2002). In situations of mineral deficiency in the diet, the hens supply this need through the process of bone reabsorption, especially from spinal bones like tibia and humerus. If calcium content in the diet is below than $2 \%$, approximately 30 to $40 \%$ of egg shell calcium will derive from bones (Mazzuco, 2006). Thus, tibia analysis aimed to verify possible differences between chlorine levels regarding bone calcium removal for eggshell formation. Considering that eggshell quality was not affected by the chlorine levels used, and the rate of diet calcium supplied poultry daily needs, there was no removal of calcium from the tibia.

Chlorine levels of water diets did not affect ( $\mathrm{P}>$ 0.05 ) the blood parameters assessed (Tab. 3 ).

Poultry can adopt some regulatory mechanisms to maintain homeostasis. In this case, there was a reduction in water consumption with levels of $20 \mathrm{ppm}$ of chlorine or more considered as a body mechanism to prevent changes in the balance of electrolytes. The kidneys participate in the control of chlorine plasma levels promoting excretion or reabsorption, and it is an important way of preventing hyperchloremia, which results in metabolic acidosis. In the hemogasometric evaluation, values of $\mathrm{pH}, \mathrm{PaCO}_{2}, \mathrm{HCO}_{3}^{-}$, electrolytes and anion gap are of fundamental importance to assess the main changes in acidbase balance. Also, they are used to determine whether a treatment produces metabolic or respiratory acidosis or alkalosis (Morais and Biondo, 2007). In this study, the variables remained in acceptable ranges.

The Anion Gap (Borges et al., 2003; Morais and Biondo, 2007), which is the difference between cations (sodium and potassium) and anions (chloride and bicarbonate), was not statistically altered by the addition of chlorine. The coefficient of variation between levels of chlorine $(41.9 \%)$ contributed for no detection of statistical differences. This variable had a small decrease in laying hens receiving water with $100 \mathrm{ppm}$ of chlorine (16,5 mmol.L-1), which could suggest that values above this level may produce acid-base balance disorders. Alterations in $\mathrm{H}^{+}$ion concentrations, and consequently, in 
basic acid balance, may trigger changes in various chemical reactions resulting in a performance decrease, poor eggshell quality and lower resistance to thermal stress (Vieites et al., 2004).

Table 3. Arterial hemogasometry, hydrogenionic potential $(\mathrm{pH})$, Carbon dioxide partial pressure $\left(\mathrm{PaCO}_{2}\right)$, Oxygen partial pressure $\left(\mathrm{PaO}_{2}\right)$, Sodium $\left(\mathrm{Na}^{+}\right)$, Potassium $\left(\mathrm{K}^{+}\right)$, Chlorine $\left(\mathrm{Cl}^{-}\right)$, Bicarbonate $\left(\mathrm{HCO}_{3}^{-}\right)$, Carbon dioxide total concentration $\left(\mathrm{ctCO}_{2}\right)$, anion $\mathrm{Gap}(\mathrm{AG})$, Oxygen saturation $\left(\mathrm{SatO}_{2}\right)$ from lightweight laying hens receiving drinking water with different levels of chlorine*

\begin{tabular}{|c|c|c|c|c|c|c|}
\hline \multirow[b]{2}{*}{ Variables } & \multicolumn{4}{|c|}{ Levels of chlorine in water } & \multirow[b]{2}{*}{$\begin{array}{c}P \text { value - } \\
\text { Duncan } \\
\text { Test }\end{array}$} & \multirow[b]{2}{*}{$\begin{array}{c}P \text { value - } \\
\text { Regression } \\
\text { analysis }\end{array}$} \\
\hline & $5 p p m$ & 20ppm & $50 \mathrm{ppm}$ & 100ppm & & \\
\hline $\mathrm{pH}$ & 7.4 & 7.4 & 7.4 & 7.4 & 0.055 & 0.463 \\
\hline $\mathrm{PaCO}_{2}(\mathrm{mmHg})$ & 46.1 & 37.1 & 40.5 & 38.1 & 0.137 & 0.459 \\
\hline $\mathrm{PaO}_{2}(\mathrm{mmHg})$ & 65.4 & 64.8 & 67.8 & 66.7 & 0.838 & 0.715 \\
\hline $\mathrm{Na}^{+}\left(\mathrm{mmol} . \mathrm{L}^{-1}\right)$ & 167.3 & 165.8 & 165.5 & 166.7 & 0.982 & 0.924 \\
\hline $\mathrm{K}^{+}\left(\mathrm{mmol} \cdot \mathrm{L}^{-1}\right)$ & 3.7 & 3.8 & 3.6 & 3.9 & 0.932 & 0.847 \\
\hline $\mathrm{Cl}^{-}\left(\mathrm{mmol} \cdot \mathrm{L}^{-1}\right)$ & 125.0 & 126.0 & 123.8 & 125.8 & 0.618 & 0.707 \\
\hline $\mathrm{HCO}_{3}^{-}\left(\mathrm{mEq} \cdot \mathrm{L}^{-1}\right)$ & 24.9 & 27.5 & 25.2 & 27.8 & 0.095 & 0.177 \\
\hline $\operatorname{ctCO}_{2}(\%)$ & 26.8 & 25.6 & 25.4 & 28.3 & 0.274 & 0.138 \\
\hline $\mathrm{AG}\left(\mathrm{mmol} \cdot \mathrm{L}^{-1}\right)$ & 20.6 & 18.9 & 20.7 & 16.5 & 0.787 & 0.138 \\
\hline $\mathrm{SatO}_{2}(\%)$ & 86.5 & 90.8 & 89.7 & 91.2 & 0.189 & 0.259 \\
\hline
\end{tabular}

* Statistically significant differences were not found $(\mathrm{P}>0.05)$.

$P$ value: Probability

\section{CONCLUSION}

Levels above $5 \mathrm{ppm}$ of chlorine in drinking water of lightweight laying hens are not recommended.

\section{REFERENCES}

AMARAL, L.A.; NADER FILHO, A.; ISA, H.; BARROS, L.S.S. Qualidade higiênico-sanitária e demanda de cloro da água de dessedentação de galinhas de postura coletadas em bebedouros tipo nipple e taça. Rev. Bras. Cienc. Avic., v.3, p.249255,2001

AUSTIC, R.E. Excess dietary chloride depresses eggshell quality. Poult., Sci., v.63, p.1773-1777, 1984.

BEZERRA, R.M.; FREITAS, E.R.; NASCIMENTO, G.A.J. et al. Níveis de cloro para codornas japonesas em crescimento e seus efeitos na fase de produção. Semin. Ciênc. Agrár., v.34, p.853-862, 2013.

BORGES, S.A.; MAIORKA, A.; SILVA, A.V.F. Fisiologia do estresse calórico e a utilização de eletrólitos em frangos de corte. Ciênc. Rural, v.33, p.975-981, 2003.
BRASIL. Ministério da Agricultura, Pecuária e Abastecimento. Instrução Normativa $\mathrm{N}^{\mathrm{o}} 56 \mathrm{de}$ $4 / 12 / 2007$. Estabelece os procedimentos para registro, fiscalização e controle de estabelecimentos avícolas de produção e comerciais. Brasília: Diário Oficial da União, Brasília, 4 dez. 2007.

CHEN, J.; BALNAVE, D. The influence of drinking water containing sodium chloride on performance and eggshell quality of a modern colored layer strain. Poult. Sci., v.80, p.91-94, 2001.

CLASEN, T.; EDMONDSON, P. Sodium dichloroisocyanurate (NaDCC) tablets as an alternative to sodium hypochlorite for the routine treatment of drinking water at the household level. Int. J. Hyg. Environ. Health, v.209, p.173181, 2006.

COTTA, T. Galinha: produção de ovos. Viçosa: Aprenda fácil, 2002. 280p.

DAMRON, B.L.; FLUNKER L.K. Broiler chick and laying hen tolerance to sodium hypochlorite in drinking water. Poult. Sci., v.72, p.1650-1655, 1993. 
FARIA, D.E.; JUNQUEIRA, O.M.; DUARTE, K.F. Enfermidades nutricionais. In: BERCHIERI JÚNIOR, A.; SILVA, E.N.; FÁBIO, J.D. et al. Doenças das aves. 2.ed. Campinas: Facta, 2009. cap.8, p.927-971.

FURLAN, R.N.; MACARI, M.; MALHEIROS, E.B. et al. Efeito da cloração da água de beber e do nível energético da ração sobre o ganho de peso e consumo de água em frangos de corte. Rev. Bras. Zootec., v.28, p.542-547, 1999.

GEZEN, S.S.; EREN, M.; DENIZ, G. The effect of different dietary electrolyte balances on eggshell quality in laying hens. Rev. Méd. Vét., v.156, p.491-497, 2005.

HAMDULLAH, K.M.Z.; KHAN, A.; JAVED, I. Toxico-pathological effects of sodium hypochlorite administration through drinking water in female Japanese quail (Coturnix japonica). Hum. Exp. Toxicol., v.29, p.779-788, 2010.

KARE, M.R. et al. The Sense of Taste in the Fowl. Poult. Sci., v.36, p.129-138, 1956.

KHAN, A.; ULLAH, M.; KHAN, M.Z. Pathological effects of sodium hypochlorite administration through drinking water in male Japanese quails (Coturnix japonica). Hum. Exp. Toxicol., v.27, p.773-780, 2008.

LEESON, S.; SUMMERS, J.D. Commercial poultry nutrition. 2.ed. Guelph: University Books, 1997. 101p.

LITTEL, R.C. et al. SAS for mixed models. 2.ed. Cary: SAS Institute, 2006. 813p

MACARI, M. Água na avicultura industrial. Jaboticabal: FUNEP, 1996. 128p.

MACARI, M.; FURLAN, R.L.; GONZALES, E. Fisiologia aviária aplicada a frangos de corte. 2.ed. Jaboticabal: FUNEP/UNESP, 2002. 375p.
MAZZUCO, H. Integridade óssea em poedeiras comerciais: influência de dietas enriquecidas com ácidos graxos poliinsaturados e tipo de muda induzida. Concórdia: EMBRAPA CNPSA; 2006. 12p. (Circular técnica, n.47).

MORAIS, H.A.; BIONDO, A.W. Distúrbios relacionados ao cloro: hiper e hipocloremia. In: DIBARTONA, S.P. Anormalidades de fluidos, eletrólitos e equilíbrio ácido-básico na clínica de pequenos animais. 3.ed. São Paulo: Roca, 2007. [p.80-90].

ROSTAGNO, H.S.; ALBINO, L.F.T.; DONZELE, J.L. et al. Tabelas brasileiras para aves e suínos: composição de alimentos e exigências nutricionais. 2.ed. Viçosa: UFV; 2005. 186p.

SENS, D.R. Influência da restrição da água na produção e peso de ovos. Rev. Agrogeoambiental, v.2, p.71-74, 2010.

SILVA, D.J.; QUEIROZ, A.C. Análise de alimentos: métodos químicos e biológicos. 3.ed. Viçosa: UFV, 2004. 235p.

SAS. Statistical analysis system. Release 9.1. (Software). Cary: USA, 2003.

VALIAS, A.P.G.S.; SILVA, E.N. Estudo comparativo de sistemas de bebedouros na qualidade microbiológica da água consumida por frangos de corte. Rev. Bras. Cienc. Avic., v.3, p.83-89, 2001 .

VIEITES, F.M.; MORAES, G.H.K.; ALBINO, L.F.T. et al. Balanço eletrolítico e níveis de proteína bruta sobre o desempenho de pintos de corte de 1 a 21 dias de idade. Rev. Bras. Zootec., v.33, p.2076-2085, 2004.

YOSELEWITZ, A.; BALNAVE, D. The influence of saline drink ink water on the activity in the shell gland of laying hens. Aust. J. Agric. Res., v.40, p.1111-1115, 1989. 